\title{
UPAYA MENGATASI GOLPUT PADA PEMILU 2014
}

\author{
Lidya Wati Evelina ${ }^{1}$; Mia Angeline ${ }^{2}$ \\ ${ }^{1,2}$ Marketing Communication Department \\ Faculty of Economics and Communication, BINUS University \\ Jln. K.H. Syahdan No. 9, Palmerah, Jakarta Barat 11480 \\ ${ }^{1}$ lidiaevelina@yahoo.com; ${ }^{2}$ f.angeline@gmail.com
}

\begin{abstract}
Data from General Election Commission (KPU) said the 2009 election abstentions level is still relatively high , ie 49,212,161 non voters (29.1\%) of the 176,411,434 voters. The low political participation of Indonesian society is caused by many cases convoluting political parties, the lack of potential figure of political parties, and the decline of the party's image. Research aims to find the 2014 election socialization efforts of the General Election Commission to reduce the level of abstentions and how the media shape public opinion to reduce the abstentees. Research used qualitative method with data collection through interview and literature. Data were analyzed with data reduction and triangulation. The study found the socialization media used for 2014 election were national and regional media socializing to various schools and universities in Indonesia. KPU also recruited agents of socialization in 2014, put up posters and banners, did activities along with agents of socialization, and increased the number of polling stations (TPS). KPU disseminated the information to the mass media to be publicized. The goal is to involve the community and to contribute to the success of the election. Electronic mass media need to make a program that helps the socialization of the election, for example having an open debate of all parties participating in the election in a special slot provided by the government then they explain the program and their pro-people commitments. As conclusions, the commission and the media have not been systematically designing programs that can persuade public to participate in the election of 2014. Research recommends the media to make a program that is interactive and engaging based on local tastes and culture to provide a common understanding about the 2014 election.
\end{abstract}

Keywords: abstain, general election commission, national election

\section{ABSTRAK}

Data KPU menyebutkan tingkat golput pemilu 2009 masih tergolong tinggi, yaitu 49,212,161 (29,1\%) dari 176,411,434 pemilih tetap. Rendahnya partisipasi politik masyarakat Indonesia disebabkan banyak kasus yang membelit partai, minimnya figur potensial yang dimiliki partai politik, dan turunnya citra partai. Penelitian bertujuan untuk mengetahui upaya sosialisasi pemilu 2014 dari KPU untuk menurunkan tingkat golput dan cara media membentuk opini publik untuk mengurangi golput. Metodologi penelitian yang digunakan adalah kualitatif dengan mengumpulkan data melalui wawancara dan studi pustaka. Data dianalisis dengan reduksi data dan triangulasi. Hasil penelitian menyebutkan media sosialisasi pemilu 2014 adalah media nasional dan daerah yang mensosialisasikan pemilu ke berbagai sekolah dan perguruan tinggi di Indonesia. Informasi juga dilakukan dengan merekrut agen sosialisasi 2014, memasang poster dan spanduk, melakukan kegiatan bersama agen sosialisasi, dan menambah jumlah TPS. KPU menyebarkan informasi kegiatan sosialisasi ini kepada media massa untuk diliput dan dipublikasikan. Tujuannya melibatkan masyarakat untuk berperan bagi kesuksesan pemilu. Media TV dan radio perlu membuat program yang membantu sosialisasi pemilu seperti acara debat terbuka semua partai peserta pemilu di slot khusus yang disediakan pemerintah, lalu jelaskan program dan komitmen pro rakyat mereka. Sebagai simpulan, KPU dan media belum merancang dengan sistematis program yang dapat mempersuasi masyarakat agar berpartisipasi dalam pemilu 2014. Disarankan media membuat program yang bersifat interaktif dan menarik berdasarkan selera masyarakat lokal dan untuk pemahaman bersama tentang pemilu 2014.

Kata kunci: golput, KPU, pemilu 


\section{PENDAHULUAN}

Data KPU menyebutkan dalam tiga pemilu nasional terakhir dan pelaksanaan pemilu kepala daerah (pemilukada) di berbagai daerah menunjukkan indikasi penurunan jumlah partisipasi pemilih. Pada pemilu nasional, yaitu pemilu 1999 (92\%), pemilu 2004 (84\%), dan pemilu 2009 (71\%) menjadi salah satu tantangan yang dihadapi dalam upaya untuk mewujudkan kesuksesan Pemilu 2014. Sementara tingkat golput dalam pemilu 2009 sebesar 49.212 .161 (29,1\%) dari 176.411 .434 pemilih tetap (www.kpu.go.id).

Banyak faktor yang menjadikan tingkat partisipasi mengalami penurunan, antara lain jenuh dengan frekuensi penyelenggaraan pemilu yang tinggi, ketidakpuasan atas kinerja sistem politik yang tidak memberikan perbaikan kualitas hidup, kesalahan administratif penyelenggaraan pemilu, adanya paham keagamaan anti demokrasi, dan melemahnya kesadaran masyarakat tentang pentingnya pemilu sebagai instrumen transformasi sosial. Alasan lain sekarang ini karena banyaknya kasus yang membelit partai, minimnya figur potensial yang dimiliki partai politik serta turunnya citra partai.

Menurut anggota KPU, Ferry Kurnia Rizkiyansyah, target partisipasi pemilih pada Pemilu 2014 diharapkan akan meningkat. Partisipasi akan meningkat sebesar 75 persen dibanding pada pemilu 2009 yang hanya 71 \%. Ferry merasa optimis partisipasi akan meningkatan bila ada Penguatan daftar pemilih. Kesuksesan dalam hal pendaftaran pemilih juga merupakan hal yang utama diungkapkan oleh pengamat politik, Samsul Hidayat dari Universitas Paramadina di Jakarta.

Samsul Hidayat juga berpendapat golput dapat dikurangi dengan membangun komunikasi dengan publik, yaitu sosialisasi yang dilakukan oleh KPU. Hal kedua untuk mengatasi golput adalah melakukan perubahan yang signifikan dalam jangka waktu pendek untuk menampilkan citra positif dengan kampanye kreatif sehingga menimbulkan minat rakyat untuk berpartisipasi dalam pemilu.

Penilaian untuk keberhasilan pemilu, dapat menggunakan ukuran secara normatif yakni pemilu berjalan lancar, dan output atau luaran yang dihasilkan sesuai dengan harapan rakyat. Masalah pendaftaran pemilu merupakan suatu masalah yang cukup besar. Di sisi lain, output pemilu perlu mengusung figur-figur baru agar Pemilu tersebut dapat berkualitas.

Salah satu keberhasilan pemilu dapat dilihat dari tingkat partisipasi pemilihnya, selain parameter-parameter lainnya seperti kemampuan mengelola konflik dan terpilihnya individu yang kredibel. Pemilihan umum jangan hanya dilihat sebagai sebuah aktifitas administratif belaka, namun lebih menekankan pada makna substansinya. Pada konteks ini, pemilihan harus didesain agar dapat menjadi sebuah pesta rakyat yang menghibur (electiontainment). Produk sosialisasi dan pendidikan pemilih harus dikemas dalam bentuk yang menghibur, ringan, dan lebih dekat dengan kultur masyarakat. Model sosialisasi seperti ini akan melibatkan industri hiburan massal seperti olah raga, budaya, maupun musik.

Pasal 308 UU No. 8 Tahun 2012 tentang Pemilihan Umum Anggota DPR, DPD, dan DPRD memuat ruang bagi penegak hukum untuk menjerat siapapun yang memaksa orang lain untuk golput. Pasal ini mengancam dengan pidana siapapun yang dengan sengaja menggunakan kekerasan dan/atau menghalangi seseorang yang akan melakukan haknya untuk memilih, melakukan kegiatan yang menimbulkan gangguan ketertiban dan ketenteraman pelaksanaan pemungutan suara, atau menggagalkan pemungutan suara.

Meskipun demikian, Koordinator Badan pekerja Kontras, Haris Azhar (dalam ADY \& MYS, 2014), mengecam pandangan yang menyebut golput bisa dipidana. Memilih atau tidak memilih adalah hak yang dijamin hukum. Dengan kata lain, golput juga dikenal di banyak negara. "Abstain ataupun menentukan pilihan dari yang tersedia merupakan ekspresi partisipasi dalam politik," ujar Azhar. 
Azhar juga menjelaskan Pasal 28 UUD RI 1945 dan pasal 23 UU HAM menjamin hak tersebut. Dalam dokumen resmi PBB tentang hak dan partisipasi dalam politik menyebut negara pihak, termasuk Indonesia, menjamin hak atas kebebasan berekspresi. Jadi, kalau ada larangan untuk golput, Haris menyebut larangan itu antidemokrasi dan anti rule of law. Pasal 308 UU Pemilu juga harus dibaca jelas karena yang dilarang adalah tindakan pemaksaaan untuk memilih atau tidak. "Pelarangan golput itu merupakan bagian pelanggaran hukum,” tuturnya.(ADY \& MYS, 2014)

Peneliti Lembaga Studi dan Advokasi Hak Asasi Manusia (Elsam), Wahyudi Jafar, juga menilai aneh pandangan tentang kriminalisasi golput. Sebab, ada 'hak politik yang dilindungi, termasuk hak untuk tidak memilih'. Apalagi kalau masyarakat sudah jenuh pada parpol. Ia menunjuk pasal 25 Konvensi Internasional tentang Hak Sipil dan Politik (ICCPR) dan Ia juga tak sepakat UU ITE bisa digunakan kepada orang yang mengajak golput melalui media sosial seperti facebook atau twitter. “Itu kan tidak masuk konten yang dilarang dalam UU ITE,” ujarnya. (ADY \& MYS, 2014)

Direktur Eksekutif Lingkar Madani (Lima), Ray Rangkuti, juga punya pandangan senada. Ia mengecam pejabat intelijen, pemerintah, atau Bawaslu yang cenderung menyalahkan orang yang golput. Menurut dia, pasal 308 UU pemilu tak hanya menyasar pemaksaan untuk memilih atau tidak memilih. Penyelenggara pemilu yang dengan sengaja membuat warga negara tidak memilih pun bisa dipidana. Karena itu ia meminta pernyataan tentang golput bisa dipidana ditarik kembali. "Kami minta mereka mengkoreksi pernyataan mereka. Pernyataan itu melanggar Undang-Undang,” katanya (ADY \& MYS, 2014).

Penelitian ini dilakukan untuk mencari media sosialisasi pemilu 2014 yang digunakan KPU untuk menurunkan tingkat golput dan cara media membentuk opini publik untuk mengurangi golput. Rumusan masalah dalam penelitian ini adalah sebagai berikut. Pertama, apa saja upaya sosialisasi pemilu 2014 yang digunakan oleh KPU untuk menurunkan tingkat golput. Kedua, bagaimana cara media membentuk opini publik untuk mengurangi golput.

\section{METODE}

Penelitian dilakukan dengan menggunakan metode kualitatif deskriptif. Riset kualitatif menggunakan cara berpikir induktif, berangkat dari hal-hal yang khusus (fakta empiris) menuju halhal yang umum (tataran konsep). Riset deskriptif membuat deskripsi secara sistematis, faktual, dan akurat tentang fakta-fakta dan sifat-sifat objek tertentu (Kriyantono, 2012:69).

Pengumpulan data dilakukan melalui wawancara, studi pustaka, dan melakukan observasi melalui literature review dari sejumlah artikel di media massa online. Beberapa hal berikut disarankan dalam melakukan wawancara: jika melakukan wawancara dengan bertatap muka, dengan menggunakan peralatan merekam yang layak; menyusun tata cara wawancara; menetukan lokasi yang baik dan jangan lupa tempat yang mendukung kualitas rekaman wawancara; setibanya di tempat wawancara, meminta persetujuan dari narasumber yang akan diwawancarai; selama proses tanya jawab, fokus pada pertanyaan, jika memungkinkan selesaikan saat itu juga, menunjukkan sikap menghargai dan seimbang, dan melemparkan beberapa pertanyaan diselingi masukan (Creswell (2007:124-125).

Lebih lanjut, Bogdan dalam Moleong (2008) mendefinisikan observasi sebagai penelitian dengan ciri interaksi sosial antara peneliti dengan subjek dalam waktu cukup lama di lingkungan subjek, dan selama itu data dalam bentuk catatan lapangan dikumpulkan secara sistematis dan berlaku tanpa gangguan. Sementara itu, Creswell (2007) menyarankan beberapa petunjuk dalam melakukan

observasi. Pertama, pilih waktu dan lokasi observasi. Dapatkan persetujuan terlebih dahulu untuk memperoleh akses. Kedua, tentukan siapa, apa, dan berapa lama observasi dilakukan. Ketiga, tekankan 
peran Anda sebagai peneliti. Peran ini bisa saja sebagai orang yang terlibat sampai orang yang meneliti. Lebih baik berdiri sebagai orang luar yang dipandu oleh orang dalam. Keempat, buatlah tata cara observasi. Kelima, ingatlah hal berikut, seperti ekspresi informan, penampilan, kegiatan, acara yang saat itu terjadi, dan reaksi Anda sendiri. Keenam, apabila memunkinkan Anda dibantu dalam hal teknis. Ketijuh, setelah selesai, tinggalkan lokasi secara sopan dan jangan lupa berterima kasih.

Analisis data dilakukan dengan analisis isi kualitatif berupa kata-kata, kalimat-kalimat, atau narasi-narasi yang dapat diperoleh melalui observasi (Kriyantono, 2012:196) dan teknik yang digunakan untuk analisis tersebut yaitu teknik komparatif konstan yang meliputi tahapan-tahapan: menempatkan kejadian/data dalam kategori dan dibandingkan satu sama lainnya. Kemudian, memperluas kategori sehingga mendapat kategori data yang murni dan tidak tumpang tindih. Selanjutnya mencari hubungan antar kategori. Analisis data yang dipakai untuk penelitian ini adalah dengan mengolah data dari hasil wawancara, observasi literatur dan artikel di media massa online. Terakhir, menyederhanakan dan mengintergrasikan data ke struktur teoretif yang koheren, masuk akal, saling terkait secara logis (Kriyantono, 2012:198). Fokus penelitian ini adalah mengetahui upaya sosialisasi yang digunakan KPU untuk menekan tingkat golput 2014 dan cara media membentuk opini publik untuk mengurangi golput.

\section{HASIL DAN PEMBAHASAN}

Asri (2009) membahas masalah Golput ditinjau dari sisi hukum. Menurut Asri (2009), Golput adalah masalah yang klasik dan universal dalam kehidupan berpolitik. Pembicaraan masalah Golput selalu menjadi topik pemberitaan yang menarik menjelang pemilu di negara mana pun di seluruh dunia. Ia juga menjelaskan bahwa memilih adalah Hak bukan Kewajiban. Hal itu termuat dalam UU tentang Pemilu, yaitu UU No.10 Tahun 2008 pada Pasal 19 ayat (1) yang berbunyi: "WNI yang pada hari pemungutan suara telah berumur 17 tahun atau lebih atau sudah/pernah kawin mempunyai hak memilih. Jadi jelas bahwa itu adalah hak dari setiap orang.” Selain itu, UUD 45 sebagai UU tertinggi Negara Indonesia yang sudah diamandemen pada 1992 dan 2002 mencantumkan dalam pasal 28 E: "Pemilu dilaksanakan secara langsung, umum, bebas, rahasia, jujur, dan adil setiap lima tahun sekali." Jadi dua pernyataan di atas menjelaskan bahwa ada kebebasaan dalam hak memilih.

Perilaku golput pada masyarakat dapat dilihat dari aspek teknis, aspek politis dan ideologis, dan aspek identitas seseorang (Masitoh, Utomo, \& Widayati, 2013). Hasil penelitian Masitoh, Utomo, dan Widayati (2013) menyebutkan bahwa seseorang berperilaku golput dilihat dari aspek teknis karena ada kendala teknis yang dialami pemilih. Hal tersebut menghalanginya untuk menggunakan hak pilih. Sebagai contoh misalnya seseorang memiliki kegiatan lain pada waktu yang bersamaan pada hari pemilihan, sehingga tidak bisa datang ke TPS. Pada aspek politis perilaku golput mempunyai alasan seperti tidak percaya dengan partai, calon/kandidat, atau tidak percaya akan adanya perubahan yang lebih baik. Sedangkan dari aspek identitas seseorang bisa dilihat berdasarkan agama, tingkat pendidikan, umur, jenis kelamin, dan lainya. Dari segi agama, seseorang memutuskan untuk golput karena partai yang diharapkan tidak terpilih sebagai calon/kandidat. Misalnya, seseorang yang beragama Kristen cenderung tidak memilih partai yang mengusung Islam seperti PPP atau PKB; sedangkan pada calon atau parpol beraliran nasionalis dinilai kurang respresentatif untuk mewadahi aspirasi, maka golput akan menjadi pilihan akhir yang diambil. (Masitoh, dkk, 2013)

Pemilu dan media menjadi dua sisi dalam satu keping mata uang, keduanya saling terkait dan saling memberi pengaruh satu sama lain. Media digunakan sebagai alat yang paling strategis yang digunakan oleh peserta pemilu untuk memengaruhi pikiran dan cara pandang publik. Posisi media pada pemilu 2014 seharusnya dapat berfungsi sebagai alat untuk mengedukasi khalayak. Akan tetapi, realitasnya media dimanfaatkan oleh partai politik untuk menyampaikan pesan-pesan politiknya kepada khalayak. 
Media di Indonesia kenyataannya tidak dapat berdiri independen dalam tataran demokrasi Indonesia. Hal ini dapat dibuktikan dengan seringnya media di Indonesia memberitakan suatu hal yang tidak berimbang: ada yang diuntungkan dan ada yang dirugikan. Seharusnya media mempunyai kemampuan untuk menyampaikan kebenaran sejati kepada khalayak masyakat. Realitasnya, media dijadikan alat untuk menyampaikan misi tersembunyi dari pemangku kekuasaan yang dikemas sedemikian rupa sehingga terkesan media berada pada pihak yang benar.

Sigit Pamungkas, Komisioner KPU divisi sosialisasi, menyatakan pendidikan pemilih dan pengembangan SDM menyatakan ada beberapa strategi peningkatan sosialisasi dan partisipasi yang dapat dilakukan KPU. Di antaranya adalah dengan melibatkan kelompok-kelompok strategis, seperti pemilih pemula, kaum beragama, perempuan, penyandang disabilitas dan kaum marginal. Mereka dapat menjadi pioneer dalam sosialisasi dan peningkatan partisipasi pemilih. Menjawab tantangan ini, KPU menyelenggarakan program Relawan Demokrasi yang melibatkan kelompok masyarakat yang berasal dari 5 (lima) segmen pemilih strategis yaitu pemilih pemula, kelompok agama, kelompok perempuan, penyandang disabilitas dan kelompok pinggiran. Pelopor demokrasi akan dibentuk di setiap segmen yang kemudian menjadi penyuluh pada setiap komunitasnya. Segmentasi itu dilakukan dengan kesadaran bahwa tidak semua komunitas mampu dijangkau oleh program KPU. Selain itu segmentasi tersebut adalah strategis baik dari sisi kuantitas maupun pengaruhnya dalam dinamika sosial-plitik berbangsa dan bernegara (www.kpu.go.id).

Upaya kedua dalam sosialisasi pemilu 2014, KPU menyelenggarakan lomba desain maskot dan jingle untuk pemilu yang akan digunakan dalam media sosialisasi. Diharapkan melalui maskot dan jingle masyarakat makin paham pemilu 2014 dan menurunkan tingkat golput. Desain maskot dan jingle yang terpilih telah diumumkan pada acara launching maskot dan jingle pemilu 2014 di bulan November 2013. Acara launching diliput oleh berbagai media massa dan diunggah ke media online melalui Youtube. Penggunaan Youtube menunjukkan KPU juga ingin meraih segmen pemilih muda/pemilih pemula.

Upaya berikutnya dari KPU adalah merekrut agen sosialisasi yang bertugas membantu sosialisasi pemilu 2014 ke daerah-daerah dan seluruh pelosok Indonesia. Selain sebagai mitra KPU, agen sosialisasi perlu menjelaskan kepada masyarakat tentang pentingnya pemilu dan hak pilih serta tata cara pemilih. KPU daerah mengadakan acara sosialisasi dengan berbagai event, seperti KPU Lampung mensosialisasikan pemilu 2014 bersama agen sosialisasi dengan menggelar gowes bersama pada akhir Desember 2013. Kampanye menggunakan sepeda ini juga dilaksanakan di beberapa daerah lainnya, berguna untuk meningkatkan partisipasi pemilih dan menekan angka golput (Sulaiman, 2013).

Selain itu, untuk menurunkan tingkat golput diantara pemilih pemula, KPU memasang poster dan spanduk di sekolah-sekolah dan perguruan tinggi. Pemasangan poster dan spanduk ini tidak hanya di pusat tetapi merata hingga ke daerah. Menurut Nova Indra, Komisioner divisi sosialisasi KPU Sumbar, minimnya partisipasi pemilih pemula menjadi hal penting yang perlu dicarikan solusi, mengingat pemilih pemula berpotensi untuk golput. Nova Indra juga berharap selain para pemilih pemula dapat menggunakan hak pilihnya, mereka juga dapat berperan, dalam sejumlah kegiatan untuk mendukung sosialisasi pemilu ini ketengah masyarakat, seperti pemasangan stiker pemilu, dan ajakan memilih di lingkungan tempat tinggal mereka (Elsa, 2014). Selain stiker, KPU juga membagikan helm, rompi, dan masker kepada pengguna motor, dan penjual koran di jalan raya. Juga dengan menerbitkan buku modul yang dapat diunduh dari website KPU. Buku modul ini difokuskan untuk pemilih pemula.

Golput merupakan singkatan dari golongan putih. Makna inti dari kata golput adalah tidak menggunakan hak pilih dalam pemilu dengan berbagai faktor dan alasan. Istilah golput muncul pertama kali menjelang pemilu pertama zaman Orde Baru tahun 1971. Pemrakarsa sikap untuk tidak memilih itu, antara lain Arief Budiman, Julius Usman, dan almarhum Imam Malujo Sumali. Langkah mereka didasari pada pandangan bahwa aturan main berdemokrasi tidak ditegakkan dan cenderung 
diinjak-injak (Dander, 2012). Mengenai hal ini, Majelis Ulama Indonesia (MUI), telah mengeluarkan fatwa pada umat Islam untuk tidak menggunakan hak pilihnya atau golput dalam pemilihan presiden. Menurut Din Syamsudin, Ketua Majelis Ulama Indonesia menurut pandangan Islam, kepemimpinan itu penting, kepemimpinan itu merupakan kelanjutan dari misi kenabian (profetik) untuk mengatur agama dan kehidupan duniawi. Din menghimbau kepada umat Islam untuk menggunakan hak pilihnya dengan sebaik-baiknya dan penuh rasa tanggung jawab. (BBC, 2014)

Bagi kaum golput, memilih dalam pemilu sepenuhnya adalah hak. Kewajiban mereka dalam kaitan dengan hak pilih adalah menggunakannya secara bertanggung jawab dengan menggunakan penyerahan suara kepada tujuan pemilu, tidak hanya membatasi pada penyerahan suara kepada salah satu kontestan pemilu. Maka dari itu, kaum golput adalah mereka yang dengan sengaja dan dengan suatu maksud dan tujuan yang jelas menolak memberikan suara dalam pemilu. Dengan demikian, orang-orang yang berhalangan hadir di Tempat Pemungutan Suara (TPS) hanya karena alasan teknis, seperti tidak terdaftar, tidak termasuk dari kategori golput (Dander, 2012).

Menurut data KPU ada 3 (tiga) faktor yang memengaruhi terjadinya golput. Penyebab pertama adalah karena kesadaran politik yang membuat dirinya enggan memilih. Banyak masyarakat yang menggunakan hati nuraninya untuk menilai visi dan misi seorang calon legislatif. Salah satu warga yang golput pada pemilu 2009 lalu mengatakan tidak ada calon legislatif yang cukup baik untuk menjadi wakil rakyat. Lebih lanjut, informan tersebut menjelaskan bahwa legislatif yang terpilih tersebut tidak mampu berbuat banyak untuk mengubah kehidupan masyarakat. Alasan lainnya dikemukakan juga oleh informan berikutnya adalah dari sekian banyak legislatif, masih banyak terdapat wajah-wajah lama yang reputasinya kurang baik di masyarakat sehingga itu yang menjadi alasan untuk tidak menggunakan hak pilihnya. Alasan kedua menjadi golput karena kesalahan teknis seperti tidak terdaftar di daftar pemilih atau letak TPS yang terlalu jauh. Alasan ketiga adalah karena masyarakat yang sudah apatis.

Upaya lain untuk menghindari Golput adalah dengan menambah jumlah TPS untuk pemilu 2014. Seperti yang dikatakan oleh Moh Ilyas, Komisioner KPU Sumenep, akan menambah 201 TPS pada pemilu legislatif 2014 guna menekan angka golput. Ilyas mengatakan pada pemilu gubernur 2013, angka golput di Sumenep, Madura, mencapai 54\%. Alasan tingginya golput atau rendahnya tingkat kehadiran pemilih ke TPS karena TPS terlalu jauh dari warga. Dengan penambahan TPS diharapkan dapat menekan angka golput (Arif, 2014).

Upaya terakhir adalah meluncurkan iklan pemilu baik melalui TV maupun media massa lainnya. Dalam pemilu 2009, KPU meluncurkan iklan pemilu yang diberi tema "Jadilah pemilih yang rasional” dengan judul "Rumpi Lapak". Target sasaran iklan ini adalah tiga kelompok, yaitu golongan muda atau pemilih pemula, perempuan, dan golongan terpinggir atau kaum disabilitas. Isi materi dalam iklan pemilu tersebut ada dua hal, yaitu bagaimana mengajak pemilih cerdas dan aktif, dan teknis yaitu bagaimana cara memilih sehingga suara dapat dianggap sah. Untuk pemilu 2014, iklan pemilu tetap dijalankan melalui berbagai TV dan radio swasta di Indonesia, ditambah dengan sosialisasi pemilu melalui Talk Show yang dilakukan oleh anggota KPU Ferry Kurnia Rizkiyansyah di bulan Desember 2013.

Dari tiga alasan yang memengaruhi terjadinya golput menurut KPU, yaitu (1) kesadaran politik yang membuat seseorang enggan memilih, (2) kesalahan teknis, dan (3) masyarakat yang sudah apatis terhadap pemilu, seluruh upaya yang dilakukan KPU untuk menekan angka golput hanya dapat fokus pada alasan kedua dan ketiga saja. KPU perlu membenahi Daftar Pemilih Sementara (DPS) dan Daftar Pemilih Tetap (DPT), serta menyediakan logistik pemilu sesuai dengan kebutuhan di lapangan, kedua hal ini vital untuk menekan angka golput yang disebabkan oleh kesalahan teknis. Sedangkan untuk menggerakan masyarakat agar tidak apatis diperlukan program sosialisasi secara massal, adanya penanaman kembali nilai-nilai demokrasi dan penyadaran pentingnya pemilu bagi diri dan negara. KPU tidak dapat melakukan sosialisasi saja tanpa membenahi persoalan teknis dan logistik pemilu, 
begitu pula sebaliknya KPU tidak dapat melakukan pembenahan dari segi teknis saja tanpa melakukan sosialisasi kepada masyarakat. Sementara itu, peran terbesar untuk mengubah alasan pertama, yaitu kesadaran politik masyarakat, berada di partai politik dan bukan KPU. Banyak kasus korupsi yang melibatkan partai politik, rendahnya citra partai, dan kurangnya figur potensial menjadi alasan utama masyarakat memilih golput. Kerja keras diperlukan dari partai politik untuk menekan angka golput dari alasan pertama ini.

Untuk menjawab rumusan masalah kedua, Sigit Pamungkas, komisioner KPU divisi sosialisasi, menjelaskan konsep electiontainment. Pemilu harus didesain agar dapat menjadi sebuah pesta rakyat yang menghibur. Produk sosialisasi dan pendidikan pemilih harus dikemas dalam bentuk yang menghibur, ringan, dan lebih dekat dengan kultur masyarakat. Model sosialisasi seperti ini akan melibatkan industri hiburan massal seperti olah raga, budaya, maupun musik.

Konsep electiontainment ini sesuai dengan teori agenda setting. Dalam agenda media terdapat tiga dimensi, yaitu (1) visibilitas, (2) audiens, dan (3) valensi. Dengan menyusun program sosialisasi yang ringan dan menyenangkan, media memenuhi tiga dimensi agenda media ini. Pertama, tingkat menonjol berita terkait pemilu 2014 ini pasti menempati prioritas tinggi. Kedua, berita ataupun sosialisasi pemilu akan menonjol bagi khalayak, dibantu dengan sosialisasi off air yang dilakukan KPU. Ketiga, cara sosialisasi yang menyenangkan akan diingat dan diteruskan oleh masyarakat. Jika agenda media sudah dilaksanakan dengan tepat, akan terbentuk agenda publik, bahwa masyarakat akan merasa akrab karena program sosialisasi menggunakan kultur lokal dan hiburan massal, adanya penonjolan pribadi, yaitu relevansi kepentingan individu dengan adanya ciri pribadi yang dapat diperoleh dari program sosialisasi menggunakan kultur lokal, dan senang yaitu timbulnya ketertarikan dan kepedulian mengenai pemilu, sehingga masyarakat dengan sadar akan memilih dan menekan angka golput.

Media massa juga memiliki fungsi sebagai kontrol sosial, yaitu untuk menyampaikan kritik kepada pemerintah melalui pemberitaan yang disampaikan. Dalam menjalankan fungsinya sebagai kontrol sosial, media massa akan memberitakan berita-berita politik secara intens, terutama kasuskasus yang terkait partai politik. Efektivitas dari fungsi kontrol sosial ini bergantung pada integritas media itu sendiri dan tingkat kepercayaan publik terhadap media yang bersangkutan. Selama ini media terkesan berpihak disebabkan adanya ketidakpuasan atas sikap pemerintah dan kepemilikan media yang dimiliki oleh anggota partai politik.

Penggunaan media untuk mensosialisasikan pemilu 2014 memang diupayakan untuk membentuk suatu opini di masyarakat. Opini masyarakat itu akan terbentuk berkaitan dengan citra pada publik. Citra tersebut dibentuk berdasarkan informasi yang diterima publik secara langsung maupun tidak langsung melalui media, terutama media massa yang bekerja untuk menyampaikan berbagai pesan yang umum dan aktual (Arifin, 2010:45).

Sesuai dengan teori agenda setting dan fungsi media sebagai pemberi informasi, maka media akan memberitakan berita terutama kasus yang menimpa partai politik secara terus menerus dan lebih intens. Masyarakat yang menerima berita akan mendiskusikan hingga terbentuklah agenda serta opini publik. Karena penekanan terus menerus pada kasus yang menimpa partai, masyarakat cenderung tidak percaya pada partai politik yang ada dan kemungkinan untuk golput makin besar. Opini publik ini yang akan mendesak pemerintah untuk mengambil kebijakan publik atau segera bertindak tegas. Jika opini publik terus meluas, dan pemerintah tidak bertindak cepat, ketidakpuasan yang berujung pada ketidakpercayaan pemerintah akan terjadi. Oleh karena itulah media memegang peranan penting untuk membentuk opini publik, yang bertujuan untuk mendesak kebijakan publik yang diambil pemerintah agar tidak merugikan rakyat dan negara.

Selama ini berita yang diprioritaskan oleh media adalah kasus-kasus korupsi yang menyeret anggota partai politik dan belum fokus pada sosialisasi golput di masyarakat. Media massa masih 
menunggu program KPU untuk sosialisasi golput ini. Seharusnya media memiliki inisiatif untuk memberitakan sosialisasi golput agar terbentuk agenda publik yang berujung pada terbantunya pemerintah dan penegakan demokrasi karena tingkat golput yang dapat ditekan. Peran media massa dalam membentuk opini publik untuk menurunkan tingkat golput masih minim; peran utama masih tetap dipegang oleh KPU. Lebih lanjut, menurut David Moonada, perilaku non-voting yaitu pertama, menekankan pada karakteristik sosial dan psikologi pemilih serta karakteristik institusional sistem pemilu; dan kedua, menekankan pada harapan pemilih tentang keuntungan dan kerugian atas keputusan mereka untuk hadir atau tidak hadir memilih (dalam Arianto, 2011).

\section{SIMPULAN}

KPU telah melakukan beberapa upaya untuk mensosialisasikan pemilu 2014 kepada masyarakat, antara lain melalui perekrutan relawan demokrasi hingga ke pelosok-pelosok yang melibatkan kelompok masyarakat yang berasal dari 5 segmen pemilih strategis yaitu pemilih pemula, kelompok agama, kelompok perempuan, penyandang disabilitas dan kelompok pinggiran. Pelopor demokrasi akan dibentuk di setiap segmen yang kemudian menjadi penyuluh pada setiap komunitasnya. Upaya kedua dalam sosialisasi pemilu 2014, KPU menyelenggarakan lomba desain maskot dan jingle untuk pemilu yang akan digunakan dalam media sosialisasi.

Upaya berikutnya dari KPU adalah merekrut agen sosialisasi yang bertugas membantu sosialisasi pemilu 2014 ke daerah-daerah dan seluruh pelosok Indonesia. Selain sebagai mitra KPU, agen sosialisasi perlu menjelaskan kepada masyarakat tentang pentingnya pemilu dan hak pilih serta tata cara pemilih. KPU juga mengadakan event bersama agen sosialisasi untuk menarik minat masyarakat terhadap pemilu. Selain itu, untuk menurunkan tingkat golput diantara pemilih pemula, KPU memasang poster dan spanduk di sekolah-sekolah dan perguruan tinggi.

Upaya lainnya adalah dengan menambah jumlah TPS untuk pemilu 2014. Upaya terakhir adalah meluncurkan iklan pemilu baik melalui TV maupun media massa lainnya. Untuk pemilu 2014, iklan pemilu tetap dijalankan melalui berbagai TV dan radio swasta di Indonesia, ditambah dengan sosialisasi pemilu melalui Talk Show yang dilakukan oleh anggota KPU Ferry Kurnia Rizkiyansyah di bulan Desember 2013.

Komisioner KPU divisi sosialisasi, menjelaskan konsep electiontainment. Pemilu harus didesain agar dapat menjadi sebuah pesta rakyat yang menghibur. Produk sosialisasi dan pendidikan pemilih harus dikemas dalam bentuk yang menghibur, ringan, dan lebih dekat dengan kultur masyarakat. Jika dijalankan dengan baik, konsep ini akan sesuai dengan teori agenda setting dan dapat membentuk agenda media, agenda publik, serta agenda kebijakan. Media saat ini hanya fokus pada pemberitaan kasus-kasus terkait partai politik, yang dapat menyebabkan masyarakat tidak percaya dan cenderung memilih untuk menjadi golput.

KPU dan media belum merancang dengan sistematis program yang dapat mempersuasi masyarakat berpartisipasi dalam pemilu 2014. Seharusnya, media juga berinisiatif untuk melakukan sosialisasi pemilu 2014, dan bukan hanya menunggu dari KPU. Peran media massa dalam membentuk opini publik untuk menurunkan tingkat golput masih minim; peran utama masih tetap dipegang oleh KPU. Disarankan media membuat program yang bersifat interaktif dan menarik berdasarkan selera masyarakat lokal dan untuk pemahaman bersama tentang pemilu 2014. Konsep electiontainment perlu dikembangkan menjadi program acara, iklan, atau talkshow agar dapat mendorong publik untuk berpartisipasi sebagai pemilih dalam pemilu 2014.

Dari tiga alasan yang memengaruhi terjadinya golput menurut KPU, yaitu (1) kesadaran politik yang membuat seseorang merasa enggan memilih, (2) kesalahan teknis, dan (3) masyarakat yang sudah apatis terhadap pemilu, seluruh upaya yang dilakukan KPU untuk menekan angka golput 
hanya dapat fokus pada alasan kedua dan ketiga saja. Untuk alasan pertama diperlukan kerja keras partai politik dan anggotanya agar bebas dari kasus korupsi. Selain dari KPU, perlu ada kesadaran dari diri masyarakat sebagai pemilih bahwa setiap suara sangat berperan untuk menegakkan negara demokrasi, dan juga melakukan penelitian mendalam terhadap wakil-wakil rakyat sebelum memilih untuk menghindari kekecewaan dan ketidakpercayaan kepada pemerintah.

\section{DAFTAR PUSTAKA}

ADY., \& MYS. (2014). Golput Bukan Tindakan Pidana. Diakses 3 Desember 2014 dari http://www.hukumonline.com/berita/baca/lt530ef7ca24424/golput-bukan-tindakan-pidana

Arianto, B. (2011). Analisis penyebab masyarakat tidak memilih dalam pemilu. Jurnal Ilmu Politik dan Ilmu Pemerintahan, 1(1), 51-60. Diakses dari http://fisip.umrah.ac.id/wpcontent/uploads/2012/03/JURNAL-ILMU-PEMERINTAHAN-BARU-KOREKSIlast_57_66.pdf

Arif. (2014, 10 Februari). Minimalisir Golput, KPU Tambah TPS. Diakses 13 Februari 2014 dari http://portalmadura.com/minimalisir-golput-kpu-tambah-tps-6158

Arifin, A. (2010). Opini Publik. Depok: Gramata.

Asri, D. P. B. (2009). Pemenuhan hak asasi manusia terhadap hak untuk memilih dan tidak memilih (golput) dalam pemilu 2009. Jurnal Konstitusi, 2(1), 7-24. Diakses 2 Desember 2014 dari http://www.mahkamahkonstitusi.go.id/public/content/infoumum/ejurnal/pdf/ejurnal_Jurnal\%2 0Konstitusi\%20UMY\%20Vol\%202\%20no\%201.pdf

Creswell, J.W. (2007). Qualitative Inquiry and Research Design: Choosing among five approaches (2nd ed.). Thousand Oaks, CA: Sage.

Dander, M. (2012, 10 Januari). Pengertian Golput dalam Pemilu. Diakses 14 Februari 2014 dari http://www.ppkdander.org/2012/10/pengertian-golput-dalam-pemilu.html

Elsa. (2014, 13 Februari). Minimalisiri Golput, KPU Pasang Sarana Sosialisasi. Diakses 14 Februari 2014 dari http://www.kpusumbarprov.go.id/index.php?option=com_content\&view=article\&id=266:minimalisiri-golputkpu-pasang-sarana-sosialisasi\&catid=14:berita-provinsi\&Itemid=105

Kriyantono, R. (2012). Public Relation \& Crisis Management. Jakarta: Kencana Prenda.

Kriyantono, R. (2012). Teknik Praktis Riset Komunikasi (Cetakan ke-6). Jakarta: Kencana Prenada.

Masitoh, D., Utomo, S., \& Widayati, W. (2013). Fenomena golput pada Pilkada Pati. Jurnal Ilmu $\begin{array}{lllll}\text { Pemerintahan. } & \text { Diakses } & 2 & \text { Desember } & 2014\end{array}$ http://download.portalgaruda.org/article.php?article=72917\&val=4924

Moleong, L. J. (2008). Metodologi Penelitian Kualitatif. Bandung: Remaja Rosdakarya.

MUI: Golput diharamkan dalam pilpres. (2014, 7 Juli). BBC.co.uk. Diakses 3 Desember 2014 dari http://www.bbc.co.uk/indonesia/berita_indonesia/2014/07/140707_golput_haram_mui

Sulaiman. (2013, 31 Desember). Tekan Golput, KPU Gelar Gowes Bersama Agen Sosialisasi. Diakses 14 Februari 2014 dari http://lampost.co/berita/tekan-golput-kpu-gelar-gowesbersama-agen-sosialisasi 